\title{
VISUAL PLEASURE IN KAWABATA YASUNARI'S NOVELLA HOUSE OF THE SLEEPING BEAUTIES
}

\author{
Ida Purnama Sari ${ }^{1 *}$; Wening Udasmoro² \\ 1,2 Department of Language and Literature, Faculty of Cultural Sciences, Universitas Gadjah Mada \\ Jl. Dr. Saharjo No. 83, RT. 13/RW.8, Manggarai, Tebet, Jakarta 12850, Indonesia \\ 'sariidapurnama15@gmail.com; ${ }^{2}$ weningw@yahoo.com
}

Received: $29^{\text {th }}$ July 2020/Revised: $10^{\text {th }}$ August 2020/Accepted: $07^{\text {th }}$ September 2020

How to Cite: Sari, I. P., \& Udasmoro, W. (2020). Visual pleasure in Kawabata Yasunari's novella house of the sleeping beauties. Lingua Cultura, 14(2), 187-193. https://doi.org/10.21512/lc.v14i2.6601

\begin{abstract}
The research discussed visual pleasure in Kawabata Yasunari's novella "House of the Sleeping Beauties". Women, when subject to the male gaze, had often been the objects of sexual and visual pleasure. The novella described the nyotaimori practice, in which sushi was served on the nude body of a woman for the object of male visual and sexual pleasure. The research sought to dissect and explore visual pleasure in literary work and its central positioning. Using Laura Mulvey's theory of male gaze and visual pleasure, and feminist literary studies, it employed content analysis as a method to uncover the phrases and paragraphs depicting visual pleasure in the novella. Firstly, the research finds that in practicing visual enjoyment, men use women as the objects of pleasure and fantasy. Secondly, men position women, their female bodies, and sexuality as markers of castration.
\end{abstract}

Keywords: visual pleasure, women objectification, male gaze

\section{INTRODUCTION}

Through the male gaze (Ritland, 2018), women are constructed and exposed in works of art and literature as objects of men's desires. In Japan, for example, women are commonly presented as objects of sexual pleasure, as realized through sexual intercourse and visual pleasure. In other words, women are presented as 'objects' of visual enjoyment. In her book Visual and Other Pleasures, Laura Mulvey explains that women are continuously transformed into displays, objects to be seen, viewed, and gazed at by men. Women are not presented qua women (Mulvey, 1989) but rather as the objects of men's pleasure (Agustin \& Udasmoro, 2018; Ritland, 2018). They are provided with no space to be themselves. Such practices, in which women are positioned as mere objects of sexual pleasure and visual pleasure, have existed for centuries.

This can be seen, for instance, in the practice of prostitution. Japan has one of the world's largest prostitution industries (Acadimia, 2018), which has a lengthy history of practice, legalization, and criminalization. During the Kamakura period (1185-1333), prostitution was legal and monitored by the government through the Office of Prostitution Services. Under the Ashikaga shogunate (13381573), prostitution was formally recognized as a formal profession and taxed by the ruling regime. This industry grew rapidly under the 16th-century Tokugawa shogunate, laying the foundation for modern prostitution in Japan (Peterfreud, 2010). In 1589 , for instance, Japan's largest brothel, the Nijo Yanagimachi in Kyoto (Onozawa, 2018), was replete with courtesans who used their bodies to provide men with sexual pleasure.

Diverse forms of prostitution have emerged over time. Some Japanese women, known collectively as karayuki-san, travelled abroad as men's entertainers (Sydney, 2016). Others, popularly known as geisha, became entertainers renowned for their beauty. As entertainers, these geisha were not only expected to provide visual and sexual pleasure to their clients but also to have a command of such arts, e.g. dance and music. Such geisha can still be found today. Still, other women, both Japanese and otherwise, were taken by the Japanese military as jugun ianfu (Zafarayana \& Putranti, 2015). Although they were euphemistically known as comfort women, in reality, they were sex 
slaves. Such practice was particularly common during World War II (Onozawa, 2018).

Japan is also home to various practices that exploit women's bodies for visual pleasure. For instance, nyotaimori is a practice that has yet to gain much international attention (Staden, 2015). In nyotaimori, sushi is served on a woman's nude body, being arranged to complement her features and increase consumers' visual pleasure. This pleasure is not a sexual one; consumers are prohibited from touching the models or interacting with them. Historically, nyotaimori was common among Japanese shoguns. Today, it is often practiced by Japanese gangsters or Yakuza.

One literary work that frames women as objects of visual pleasure is Kawabata Yasunari's novella 眠 れる美女 (Nemureru Bijo) translated by Edward Seidensticker as House of the Sleeping Beauties. Written by one of Japan's most famous novelists and short story writers, House of the Sleeping Beauties was first published in 1961. It follows a 67-year-old man named Eguchi. Feeling lonely in his old age, Eguchi follows his friend's recommendation and seeks pleasure at the titular house. At this secret establishment, which only serves older men, customers are allowed to sleep beside the nude young virgins. Before the customer enters the bedroom, the chosen girl is given a sleeping pill to ensure that she will sleep soundly until the following morning. Customers are subject to several rules and are prohibited from awakening sleeping girls or doing anything untoward. The girls may only be enjoyed visually; physical contact is not allowed.

In a patriarchal society, Mulvey argues that women are framed as the signifiers of men, as bearing meaning rather than creating it (Mulvey, 1989). Women, thus, exist within a symbolic framework, in which men may use language to realize their fantasies and obsessions while simultaneously silencing women. This produces a culture (including literature, cinema, and other arts) permeated by sexual inequality, with visual pleasure being divided between active subjects (men) and passive objects (women).

Men project their fantasies on women through the male gaze. They are shown as visual objects, like displays that have a visual and erotic effect on male viewers. Women are presented as sexual objects with erotic motifs to be seen rather than heard (Boyle, 2015; Mulvey, 1989). Audiences are implicitly assumed to be heterosexual men, and there is a clear distinction between men (as spectators) and women (as spectacles). When men produce meaning, and audiences are assumed to be male, women are objects of the gaze rather than owners of the gaze (Mulvey, 1989; Thornham, 2015). Thus, female characters have two simultaneous functions; to act as erotic objects for male characters (i.e., those in work), and to act as erotic objects for male audiences (in this case, readers). When women are presented in work, the male characters and audiences' gazes are combined and incorporated into existing narrative conventions (Udasmoro, 2018). Women's bodies and sexualities are, therefore, exploited to provide men with a source of sexual pleasure.

In such works, women are unconsciously used to perpetuate the patriarchy and its phallocentric worldview. As (Mulvey, 1989) writes, "the function of woman in forming the patriarchal unconscious is two-fold, she first symbolizes the castration threat by her real absence of a penis and second thereby raises her child into the symbolic." In the end, women are provided little space as creators of worldview, and their own desires are imagined as creating nothing but suffering. Women are trapped. Mulvey (1989) emphasizes that, in the male gaze, women are objects of male's sexual imaginations. Female characters are presented as expressions of men's subconscious fears and desires and do not represent women qua women. Female characters are little more than pretty faces, upon which men can project their fear of castration and emasculation.

Simultaneously, the male gaze is used to create visual pleasure and offer men a proxy for satisfying their sexual desires. In explaining this phenomenon, Mulvey (1989) borrows from Freud's understanding of psychoanalysis and sexuality. She argues that heterosexual men gaze upon women to achieve sexual satisfaction and legitimize such behavior by positioning themselves as ordinate and women as subordinate (Mulvey, 1989). To explain this gaze, she adopts two key concepts from Freud; scopophilia and narcissism. She uses the former to refer to the pleasure that is linked to sexual attraction. In his Three Essays on Sexuality, Freud (Mulvey, 1989) argues that scopophilia is a key component of sexuality and is driven by desires that emerge from erogenous zones. Through scopophilia, women are objectified by men who seek to control them to maximize their pleasure. They become objects of desire, objects of curiosity viewed through a voyeuristic lens. Freud (in Mulvey, 1989) adds that pleasure is transferred to others through analogy, creating a narcissism in which one's own perceptions are projected onto others.

Departing from Mulvey's theory of visual pleasure, the current research seeks to explore visual pleasure as presented in Kawabata Yasunari's novella House of the Sleeping Beauties. It seeks to explore how visual pleasure is presented, practiced, and emphasized in the novella, thereby showing how gender relations are not horizontal (involving men and women, as in Mulvey's theory) but hierarchical constructed by the society based on sex and sexuality.

\section{METHODS}

As a material object, the research discusses Kawabata Yasunari's novella 眠れる美女 (Nemureru Bijo), translated by Edward Seidensticker as House of the Sleeping Beauties) (Kawabata, 2017a, 2017b). As its formal object, the research uses the novella's representation of visual pleasure. The research is begun by identifying the research problem as related 
to visual pleasure in the novel. Afterward, the analysis is continued with the collection of data (phrases and paragraphs that present visual pleasure) in House of the Sleeping Beauties. Particular emphasis is given to the author's depiction of women vis-a-vis men in the novella. These data are subsequently translated from Japanese and then explained into classifications to provide a useful source for subsequent analysis, which is conducted using Mulvey's theory of visual pleasure (complemented by other theories).

\section{RESULTS AND DISCUSSIONS}

In the novella, the women treated as the objects of male pleasure are depicted as young virgins. When the main character, Eguchi, sets his eyes upon such girls while they are sleeping, he positions those girls as the objects of his gaze. This drive is depicted as an instinctual one, a sexual one, that instills Eguchi with desire for pleasure. It is the process that Mulvey, borrowing from Freud, deems scopophilia (Mulvey, 1989). Two forms of scopophilia are presented in this novella. First is the instinctual drive that emerges within Eguchi himself when he sets his eyes upon young girls who are naked and sleeping. The virgins who accompany Eguchi as he sleeps are framed as the objects of his pleasure, which he derives from laying his gaze upon their nude bodies, covered only by a single bedsheet. These girls and their bodies are made available for exploitation. Second is the stimulation that stems from the gaze, which in turn increases Eguchi's curiosity and desire, thereby promoting the practice of voyeurism. Eguchi's gaze is drawn to certain parts of these girls' bodies, all of which are deemed sensual or sexual in nature; their necks, hair, lips, breasts, hips, and knees.

In this entertainment venue, young virgins are deliberately made available to older men to fulfill their desires. The House of the Sleeping Beauties owner understands how to cater to the needs and desires of her customers. The girls are made available as the objects of men's sexual and visual desires, with their beauty being used to stimulate customers' scopophilia. This is influenced by two factors, internal and external; those that emerge within the customers themselves, and those that emerge from the nude bodies of the girls, as complemented by the rooms where they sleep. By positioning these young girls as the objects of men's pleasure, they are positioned as powerless and disenfranchised. In this novella, the male character, Eguchi, is the main character of the plot, being more powerful than the young girls who sleep at his side and whose bodies he may freely see and touch. Eguchi is presented as an active subject, one whose actions shape the plot, while the girls at the House of the Sleeping Beauties are portrayed as passive objects.

Over the course of the novella, the pleasure that Eguchi derives from gazing upon the nude bodies of sleeping girls (i.e., scopophilia) develops into narcissism. Eguchi's male gaze is stimulated, which leads to action. Eguchi feels greater stimulation when he sets his eyes upon the sleeping girls' nude breasts. As a result, he begins fantasizing about them.

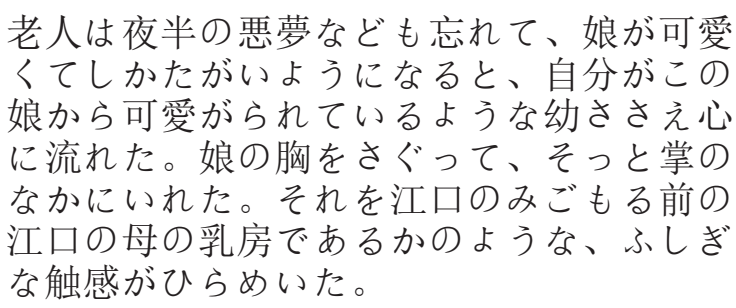

He had forgotten the nightmare, and an affection for the girl poured through him. There came over him too a childlike feeling that he was loved by the girl. He felt for a breast and held it softly in his hand. There was a strange flicker of something in the touch as if this were the breast of Eguchi's own mother before she had him inside her (Kawabata, 2017a: 39).

In his narcissism, Eguchi does not simply gaze upon the girls' nude bodies but is stimulated into touching them. When touching one girl, he imagines that the breasts of the girl do not belong to him but that of his mother in her youth. Eguchi is interested in the girl's nude body, particularly her eroticized breast, which ultimately affects all of his senses. The fantasies that emerge as Eguchi gazes upon these girls' nude bodies bring pleasure to Eguchi. He feels as though his youth's passions and strengths are returning to him, as though he is regaining the things that he lost in his 67 years on earth. Eguchi feels young again, as sleeping beside young virgins enables him to forget his age, at least for the moment, the worries of his twilight years.

In this context, an older man exerts his dominance over a young girl through his male gaze. This man is positioned by the author as a subject, as having the agency to realize his desires and his libidinal urges (Staden, 2015). However, this is ultimately a paper tiger; Eguchi lacks the power to dominate women physically and is restricted to his gaze.

In this novella, women are presented as being sources of simultaneous pleasure. Psychoanalysts argue that women have been signified by their sexual differences, by their lack of a physical penis, and are seen as reminders of the threat of castration. This is expanded to the symbolic realm and the Law of the Father, with women being signifiers for the male other, "bound by a symbolic order in which man can live out his fantasies and obsessions" (Mulvey, 1989). Women are thus not only the objects of male desire but also sources of male anxiety.

In House of the Sleeping Beauties, men are represented through the main character Eguchi and the other clients of the house. In order to soothe their anxieties, these men seek to sleep beside young girls. In Eguchi's case, he feels the anxiety of his age drifts away as he relives his youth. This anxiety and this fear of loss are also a fear of castration, which Eguchi unconsciously seeks to escape. 
かなしさとかさびしさとかいうょりも、老 年の凍りつくようななさけなさであった。 そしてそれは、若いあたたかみを匂い寄せ ている娘にたいする、あわれみといとしさ に移り变わった。

[Eguchi] felt a surge of loneliness tinged with sorrow. More than sorrow or loneliness, it was the bleakness of old age, as if frozen to him. And it changed to pity and tenderness for the girl who sent out the smell of young warmth (Kawabata, 2017a: 20).

Mulvey argues that men availed with two avenues are used to escape castration anxiety; voyeurism and fetishistic scopophilia, both of which have been touched on above (Mulvey, 1989). In the former, men reenact the original trauma by investigating the woman, demystifying her mystery, and punishing or saving her. Meanwhile, in the latter, women are transformed into a fetish by the men, such that their body gives way to reassurance and pleasure.

The latter is most prominent in Eguchi's visits to the House of the Sleeping Beauties, as he regularly uses fetishistic scopophilia to transform girls into erotic objects. Eguchi perceives the girls who sleep by his side as sexual objects, as fetishes, made available to him. As in other fetishistic scopophilia cases, women are presented by the author as powerless, and therefore easily exploited by men. When Eguchi arrives, the girls are already sound asleep and unable to resist his efforts to touch their bodies.

娘はかけぶとんを引きさげて、ひろくゆた かだけれども、高い低いのややとぼしい胸 を半分出した。その白い肌に深紅のびろう どの色がほのかにうつっていた。老人はき れいな胸をながめながら、富士額の生えぎ わの線を一本の指先きでたどってみたりし た。娘はあおむけになってから、静かに長 いいきをつづけていた。ちいさいい唇のな かに、どんな歯があるのだろう。江口は下 唇のまんなかをつまんで少し開いてみた。 骨のちいさいわりにこまかくはないが、ま あこまかい、きれいににそろった歯であっ た。老人が指をはなすと、娘はもとのょう には唇をとじきってしまわなかった。歯を 少しのぞかせたままにした。江口老人はく ちべにで赤くなった指先きを、娘の厚めの 耳たぶをつまんでこすり、残りを娘の太い 首にこすりつけた。じつに白い首にあるか ないかの赤い線がついて可愛かった。

She had thrown off the quilt, and her bosom, rich and wide but somewhat wanting in emphasis, was half exposed. The fair skin was slightly tinged in the light from the crimson velvet. Gazing at the handsome bosom, he traced the peaked hairline with her finger. She continued to breathe quietly and slowly. What sort of teeth would be behind the small lips? Taking the lower lip at its center he opened it slightly. Though not small in proportion to the size of her lips, her teeth were small all the same and regularly ranged. He took away his hand. Her lips remained open. He could still see the tips of her teeth. He rubbed off some of the lipstick at his fingertips on the full earlobe and the rest on the round neck. The scarcely visible smear of red was pleasant against the remarkably white skin (Kawabata, 2017a: 97-98).

Eguchi creates his own fetishistic object through the sexualized and sensualized parts of the girl's body, drawing pleasure from the view of her body, particularly those eroticized parts such as the breasts that Eguchi lacks as a man. His attention is drawn to the tangible and visible differences between the male and female body, particularly the distinct contour and shape of the girl's breasts. Such fetishization is further driven by culture and religion by framing the female body as taboo, only makes it more attractive to the male gaze. Eguchi takes a particular interest in the girl's breast, comparing their beauty to that of other pleasurable things. It is as though, for Eguchi, there is nothing more beautiful than a girl's supple breasts. At the same time, this fetishization enables Eguchi to identify himself by distinguishing his male body from the female body, akin to the Lacanian 'mirror stage'.

Lacan (in Sheikh, 2017; Zafiropoulos, 2016) describes the mirror stage as happening when a child first stands in front of a mirror and attempts to identify $\mathrm{him} /$ herself, ultimately concluding that he/she has a different form and image than all others. Eguchi identifies himself as distinct from the girls at his side, and this draws his curiosity. His gaze is further drawn by the beauty of their bodies that could not be rejected by any man. This beauty captivates Eguchi and alleviates his sense of loneliness. At the same time, this indicates a shortcoming in the man himself; Eguchi lacks the girls' youth. Nonetheless, owing to his sex and his seniority, he is still facilitated in maintaining dominance and in retaining control over their bodies.

During his first visit to the House of the Sleeping Beauties, Eguchi is clearly told that customers are prohibited from touching the girls that sleep by their side or acting in an untoward manner. However, Eguchi's desire and curiosity ultimately lead him to ignore these rules. He acts voyeuristically, employing the second avenue for escaping the fear of castration.

House of the Sleeping Beauties does not explicitly identify its time setting. As such, to understand the messages conveyed by Kawabata Yasunari through this novella, it is best to position it within the context of the contemporary social situation. As House of the Sleeping Beauties was first published in 1961, this means positioning the novella within the context of 1960s Japan. By doing so, a link correlation between the work and contemporary society is clearly evident. At the time, the Japanese government was implementing a series of policy reforms that transformed prostitution in the country. In 1956, the 
Japanese government passed two laws to limit the practice of prostitution; the Prostitution Prevention Law and the Anti-Prostitution Law. As both laws sought to eradicate licensed prostitution and prohibit its promotion (Peterfreud, 2010), after their passage, all brothels and other enterprises that profited directly and indirectly from the sexual exploitation of women were closed. Likewise, the practice of prostitution is made illegal.

Nonetheless, in Kawabata's novella, prostitution is still practiced (albeit secretly) at the House of the Sleeping Beauties.

… 宿屋の看板は出していない。またこの 家の秘密は、そんなものを出せぬだろう。

... Probably because its secret allowed none, there was no sign at the gate (Kawabata, 2017a: 9).

Through House of the Sleeping Beauties, Kawabata shows that the passage of the Prostitution Prevention Law and the Anti-Prostitution Law is insufficient to end the practice of prostitution in Japan. Brothels and similar businesses continue to operate in secret, as the titular house does by providing its elderly clients with visual stimulation. Despite its best efforts, the government is unable to end prostitution, as the Japanese people continued to perceive sexual fulfilment as a daily need.

In traditional Japanese society, women were marginalized both in the family and in broader society. In the family, Japanese women were expected to obey men. Before marriage, a girl had to obey her father; after marriage, she had to obey her husband; and in her old age, she had to obey her sons. Japanese women were only afforded respect after becoming mothers, and this modicum of honor did not come from their intrinsic value as women but rather from their ability to provide offspring and ensure the continuance of the family.

In broader society, Japanese women are not afforded the same rights as men. To guarantee male dominance and disenfranchise women, daughters receive little education (Peterfreud, 2010). At the same time, women are provided with few employment opportunities; when women needed an income, they could only avail themselves to such dishonorable professions as prostitution. In Kawabata's House of the Sleeping Beauties, this social structure is reflected in the girls' powerlessness. Before the arrival of their clients, the girls are coerced by men into drinking sleeping pills and are left incapable of defending themselves or resisting advances. They are provided as objects of visual pleasure, entirely under the control of their male clients.

…老人は目をそらせて部屋のなかを見まわ した。自分の脱いだものがみだれ箱にある だけで、娘の脱いだものはどこにも見あた らなかった。さきほどの女が持ち去ったの
かもしれないが、もしかすると娘はなにも つけなくてこの部屋へはいって来たのかも しれないとおもうと、江口はぎょうっとし た。娘がすっかりなまめられる。…

... [Eguchi] looked around the room. Only his own clothes were in the box. There was no sign of the girls. Perhaps the woman had taken them away, but he started up at the thought that the girl might have come into the room naked. She was to be looked at. ... (Kawabata, 2017: 19).

As the girls are sleeping naked without anything but a blanket to conceal their bodies, the men are able to enjoy the bodies freely. The author, Kawabata, presents men as wielding nigh unlimited power over women's bodies. The women know what will be happening during their sleep, but they are vulnerable to refusing it because they have to play this role for their economic purposes. Despite their advanced age and by implication, frail bodies, these men are the wielders of power (Tahnerian, 2018). Women are positioned as subordinate, while men are positioned as ordinate.

In House of the Sleeping Beauties, the male gaze is that of the character Eguchi, who controls and exploits girls' bodies while they are sleeping without their consent. At the same time, the girls are presented as passive objects, lacking the ability to determine their own fates or shape the narrative. These girls are framed as mere objects to be viewed and enjoyed by men without their consent.

$$
\begin{aligned}
& \text { ‥かし娘は眠っていてなにごとも知らな } \\
& \text { いので、娘の顔かたちはここに見る通り、 } \\
& \text { よごれもくずれもしなおのだろうか。・... }
\end{aligned}
$$

... The girl was asleep and knew nothing. Would the face and the form remain untouched and unsullied, as they were before him now?... (Kawabata, 2017: 29).

House of the Sleeping Beauties has rules that seemingly protect the girls. However, this protection is ultimately ineffective. Although the proprietress tells Eguchi in no uncertain terms how he is expected to behave, he is nonetheless able to break these rules and touch the girls' bodies as he remains unmonitored. The proprietress is unable to ascertain whether clients have touched the girls or even sexually molested their bodies. Furthermore, the girls themselves are incapable of knowing whether they have been violated in their sleep. In this narrative, the virgin girls are not constructed as women but merely as objects of men's exploitation for their own sexual satisfaction. Conversely, their male clients, despite their advanced age and frailties, are able to exert power and reclaim their masculinity. The dominant structures, wherein women are objectified by an inherently inequal gender regime, cannot be challenged (Ponterotto, 2018).

Delving further into the question of visual pleasure in House of the Sleeping Beauties, it is vital 
to consider its male author and his creation of the novella's main character and his male gaze. As the author, Kawabata Yasunari has full control over the characters, plots, and viewpoints contained within the narrative. Thus, it is his choice to employ a male perspective and take a man, Eguchi, as the main character. Likewise, it is also his choice to present female characters, including Eguchi's mother, former lovers, and the girls with whom he sleeps at the House of the Sleeping Beauties, as nameless entities. Kawabata prioritizes his male characters, giving them names (Eguchi, Kiga, and Fukura) and agency, and marginalized his female characters, identifying them merely as 'the girl' or 'the woman'. This tendency belies the author's perspective and the biases inherent to it.

This analysis shows, in House of the Sleeping Beauties, the young girls are depicted as the objects of men's pleasure and used as bodies of men. The novella's narrative shows these girls as providing visual pleasure to elderly male clients. Although this establishment has rules that are seemingly intended to protect its girls from lechery and abuse, men are ultimately able to wield unabated power. These men are provided young girls, sound asleep and incapable of resisting. As such, despite their mature age, these men wield unfettered power, flouting the rules, and fondling the girls without consent and with no repercussions.

As such, in this novella, visual pleasure is used to advance male dominance, which is compounded by the views of its author. Incapable of escaping Japanese society's restrictions, Kawabata Yasunari continues to be influenced by its patriarchal beliefs. Does he intend to reproduce the idea that men are the strong wielders of power and that women are the weak objects of power? Or, does he seek to strengthen his own position as a man? Or does he expose the women's oppression by men? All of these are possible explanations. In Kawabata's novella, women are narrated as sleeping beauties that are incapable of resisting men. This reflected contemporary Japanese society, in which women are constructed as weak and passive beings, mere passive objects to be commanded by men.

\section{CONCLUSIONS}

This analysis has shown that virgin girls are represented in Kawabata's novella House of the Sleeping Beauties as nothing but the objects of men's pleasure. Eguchi, with the establishment's other clients, derives visual pleasure from his practice of women objectification. As Eguchi employs his male gaze, his fetishistic scopophilia is transformed into a narcissism, while the stimulation derived from viewing girls' nude bodies is transformed into pleasurable fantasy. At the same time, this visual pleasure enables Eguchi to overcome the threat of castration by temporarily regaining his youth and reducing women to fetishes as well as asserting his own power through voyeurism. As a central element of Kawabata Yasunari's novella House of the Sleeping Beauties, the research of visual pleasure has made two critical findings. First, this novella was published in the 1960s, when the Japanese government was attempting to eradicate the practice of prostitution by passing new legislation. Influenced in part by Christianity, the Prostitution Prevention Law and the Anti-Prostitution Law closed Japan's brothels and prohibited the practice of prostitution. Through House of the Sleeping Beauties, Kawabata criticizes the Japanese government's policies, using the titular house to show the shortcomings of these laws.

Similarly, Kawabata Yasunari's novella House of the Sleeping Beauties uses visual pleasure to show that men retained full power over women, especially their sexuality. As such, it uses visual pleasure to legitimize men's dominance of women, simultaneously reinforcing the strong patriarchal culture of the Land of the Rising Sun and showing that Kawabata is incapable of escaping the shackles of said culture.

\section{REFERENCES}

Acadimia, K. (2018). Human traficking in Japan through the use of schoolgirls. International Research Scape Journal, 5(1), 1-20.

Agustin, E., \& Udasmoro, W. (2018). Women and pleasure in Guillaume Apollinaire's calligram collection Poèmes à Lou. Jurnal Kata, 20(2), 60-68. https://doi. org/10.9744/kata.20.2.60-67.

Boyle, K. (2015). Introduction: Visual pleasure and narrative cinema at forty. Feminist Media Studies, 15(5), 880881. https://doi.org/10.1080/14680777.2015.107527 1.

Kawabata, Y. (2017a). House of the sleeping beauties and other stories. Translated by E. Seidensticker. New York: Vintage Book.

Kawabata, Y. (2017b). Nemureru bijo. Tokyo: Shinchosha.

Mulvey, L. (1989). Visual and other pleasures. New York: Palgrave.

Onozawa, A. (2018). Comfort women and state prostitution. The Asia-Pacific Journal, 16(10), 1-26.

Peterfreud, T. (2010). Japan's prostitution prevention law: The case of the missing geisha. Law School Student Scholarship, 57, 1-31.

Ponterotto, D. (2018). Resisting the male gaze: Feminist responses to the "normalization" of the female body in western culture. The Journal of International Women's Studies, 17(1), 133-151.

Ritland, R. (2018). Visual pleasure from motherhood: Alyssa Milano changing the male gaze. Media, Culture, and Society, 40(8), 1281-1291. https://doi. org/10.1177\%2F0163443718798902.

Sheikh, F. A. (2017). Subjectivity, desire, and theory: Reading Lacan. Cogent Arts and Humanities, 4(1), 1-12. https://doi.org/10.1080/23311983.2017.12995 65.

Staden, C. (2015). Chewing on Japan: Consumption, diplomacy, and Kenny Kunene's Nyotaimori 
scandal. Critical Arts South-North Cultural and Media Studies, 29(2), 107-125. https://doi.org/10.10 80/02560046.2015.1039199.

Sydney, X. (2016). The shame of empire: Japanese overseas prostitutes and prostitution abolition in modern Japan, 1880s-1927. Positions, 24(4), 839-873.

Tahnerian, J. (2018). Copyright's male gaze: Authorship and inequality in panoptic world. Harvard Journal of Law and Gender, 4, 345-393.

Thornham, S. (2015). On visual pleasure and narrative cinema. Feminist Media Studies, 15(5), 881-884. https://doi.org/10.1080/14680777.2015.1075272.

Udasmoro, W. (2018). When the teens narrate the selves in Indonesian Literature: Gender, subject, and power. Lingua Cultura, 12(1), 53-60. https://doi. org/10.21512/lc.v12i1.1961.

Zafarayana, D., \& Putranti, I. (2015). Militer dalam kejahatan perang Jepang terhadap Indonesia tahun 1942-1945: Studi kasus perbudakan seksual wanita Indonesia. Journal International Relations, 5(1), 235-243.

Zafiropoulos, M. (2016). What Lacan said about totem and taboo. Research in Psychoanalysis, 1(21), 117-125. https://doi.org/10.3917/rep1.021.0117. 